Pak. j. sci. ind. res. Ser. A: phys. sci. 2019 62A(1) 8-19

\title{
Optimization of Reaction Parameters for the Synthesis and Metal Ion Binding Properties of a Novel Schiff Base Using Response Surface Methodology: Kinetics and Thermodynamic Studies
}

\author{
Felix Sunday Nworie*, Frank Ikenna Nwabue, Joseph Afiukwa, and Wilbforce Oti \\ Department of Industrial Chemistry, Ebonyi State University, PMB 053 Abakaliki, Ebonyi State, Nigeria
}

(received October 10, 2017; revised August 30, 2018; accepted September 4, 2018)

\begin{abstract}
This research work described the synthesis and metal ion binding properties of bis(2,2'methylylidenephenol)diaminoethane a biologically, chemically and industrially important compound to make it more suitable and efficient for industrial scale production. To optimize the relationship between reactions conditions and yield of $\mathrm{Co}(\mathrm{II})-\mathrm{H}_{2} \mathrm{BMPDE}$, a second order quadratic polynomial equation was generated. The economical operating optimal reaction parameters were $0.30 \%$ bis $\left(2,2^{\prime}-\right.$ methylylidenephenol)diaminoethane $\left(\mathrm{H}_{2} \mathrm{BMPDE}\right), 6.22 \mu \mathrm{g} \mathrm{CoCl} 2.9 \mathrm{H}_{2} \mathrm{O}$, temperature of $39.27^{\circ} \mathrm{C}$, extraction time of $14.83 \mathrm{~min}$ and $\mathrm{HCl}$ concentration of $10^{-4} \mathrm{M}$. Based on the optimized reaction parameters, the laboratory yield was $31.70 \mu \mathrm{g}$, which was in close agreement with the predicted yield of $31.89 \mu \mathrm{g}$. Thermodynamic studies indicated that the complexation is feasible, spontaneous, endothermic and involved solvation process. The high regression coefficient observed from the pseudo-second order kinetic model $\left(\mathrm{R}^{2}=0.9948\right)$ as against pseudo-first order kinetic model $\left(\mathrm{R}^{2}=0.3382\right)$ indicated that pseudo-second order kinetic model was obeyed and clearly described the complexation process. The complexation of cobalt(II) ions on the $\mathrm{H}_{2}$ BMPDE correlated well with both Langmuir $\left(\mathrm{R}^{2}=0.8822\right)$ and Freundlich $\left(\mathrm{R}^{2}=0.9979\right)$ isotherms. The response surfaces and scale-up experiments indicated that the optimized process conditions could improve the yield of the complex at larger scales.
\end{abstract}

Keywords: $\mathrm{Co}(\mathrm{II})-\mathrm{H}_{2} \mathrm{BMPDE}$ complex, response surface methodology, thermodynamic studies, industrial application

\section{Introduction}

The synthesis, characterisation and application of compounds with $\mathrm{N}_{2} \mathrm{O}_{2}$ donor atom sets has increased in recent years owing to their chemical, industrial and biological importance. Consequently, bis $\left(2,2^{\prime}\right.$ methylylidenephenol) diaminoethane and its metal complexes have been widely researched owing to their use as biologically active compound (oxygen carrying ability, antimicrobial, anti tumor and insect repellant activities) (Ansari et al., 2009; Woldemarian and Mandal, 2008), as electrolyte, antitumor agents, metal ion determination and in catalytic reduction reactions (Dardfarnia et al., 2015: Starkie, 2015; Yang et al., 2010; Doctrow et al., 2002) in red phosphorescent light emitting diodes (Bae et al., 2011) in catalytic reactions (Peiris and Udugala-Ganahenege, 2015) magnetic drug(Ishikawa and Eguchi, 2013) and other miscellaneous applications (Sakineh and Razieh, 2013; Yuan et al., 1993)

In previous years preparation of metal complexes of $\mathrm{H}_{2} \mathrm{BMPDE}$ had always followed the protocol designed

*Author for correspondence; E-mail: nworie.felix@gmail.com by Cozzi (2004) without consideration to other preparatory method. In similar way, the method of Cozzi (2004) and Ishikawa and Eguchi (2013) patented for the preparation of $\mathrm{H}_{2} \mathrm{BMPDE}$ metal magnetic drugs was discussed at laboratory scale without industrial consideration.

Box- Behnken design illustrates the interaction between variables need less number of experiments, forecasts response, handles relationship between many parameters, tackles real issues, can be manipulated and takes less time (Jiao et al., 2013; Shu et al., 2013; Wang and Chi, 2012; Zhang and Liu, 2011; Greferer and Lankmaryr, 2005). Response surface methodology (RSM) has been previously used for the removal of heavy metals from aqueous solutions using biosorbents and in the preparation of iron-polysaccharide complex (Zhang and Liu, 2011) but there is no established literature on the use of this method in extractive preparation of metal $\mathrm{H}_{2} \mathrm{BMPDE}$ complexes.

The present study is aimed at developing a novel, efficient and effective process for $\mathrm{Co}$ (II)- $\mathrm{H}_{2} \mathrm{BMPDE}$ complex preparation and produce a satisfactory process 
for large scale production of the complexes of $\mathrm{H}_{2} \mathrm{BMPDE}$. The work centered on the optimization of the process conditions for the synthesis and extraction of the complex using RSM and testing the feasibility of the process in solution, hence the equilibrium, kinetics and thermodynamics studies.

\section{Materials and Methods}

$\mathrm{CoCl}_{2} \cdot 6 \mathrm{H}_{2} \mathrm{O}, \mathrm{HCl}, \mathrm{Na}_{2} \mathrm{CO}_{3}$, chloroform, carbon tetrachloride, salicylaldehyde and ethylenediamine analytical grade reagents were obtained from Merck (Germany) and used without further purification unless otherwise stated.

Equipment. Electronic spectra of the $\mathrm{H}_{2} \mathrm{BMPDE}$ and $\mathrm{Co}(\mathrm{II})-\mathrm{H}_{2} \mathrm{BMPDE}$ complexes were obtained on Genesis 10S UV-Vis Spectrophotometer. Modeling the extraction process and the responses were done using Design Expert software version 8.0.7.1 (Stat-ease Inc., USA, 2011), Perkin-Elmer FTIR-8400S Fourier transform infrared spectrophotometer (Shimadzu, Japan) was used to obtain transmission infrared spectra of the ligand in the range of $4000-400 \mathrm{~cm}^{-1}$ in $\mathrm{KBr}$ pellets. GC-MSQ 2010 Plus (Shimadzu, Japan) coupled with gas chromatograph was used to obtain the mass spectra analysis of the ligand through electron ionization. Bruker AVANCE II $400 \mathrm{MHz}$ spectrometers with $\mathrm{CDCl}_{3}$ as solvent and tetramethylsilane as internal reference were used to record NMR spectra. Vario-Elemental Microcube ELIII was used to determine the elemental composition of $\mathrm{H}_{2}$ BMPDE.

Synthesis of bis(2,2'-methylylidenephenol) diaminoethane. $\mathrm{H}_{2} \mathrm{BMPDE}$ was prepared by the modified Takeshima procedure as described elsewhere (Ishikawa and Eguchi, 2013) by mixing ethylenediamine and salicylaldehyde in a 2:1 mole ratio, heating and recrystallization in carbon tetrachloride. Yield: 73.35 g, $64.45 \%$, M.P $=127 \pm 1{ }^{\circ}$ C. Electronic spectrum (DMF, $\left.\mathrm{nm},{ }^{\varepsilon}=\mathrm{Mol}^{-1} \mathrm{dm}^{3} \mathrm{~cm}^{-1}\right): 260\left(\varepsilon=3.0 \times 10^{2}\right), 285(\varepsilon=3.6$ x $\left.10^{2}\right) 335\left(\varepsilon=4.7 \times 10^{2}\right)$. Anal calcd. for $\mathrm{C}_{16} \mathrm{H}_{16} \mathrm{~N}_{2} \mathrm{O}_{2}$ : C, 71.64\%; H,5.97 \%; N,10.44\%. Found: C, 70.89\%; $\mathrm{H}, 6.05 \%$; N, 0.41\%. FT-IR $\left(\mathrm{KBr}, \mathrm{cm}^{-1}\right): 3401 \mathrm{~cm}^{-1} v$ (-OH), $3042 \mathrm{~cm}^{-1} \vee\left(=\mathrm{CH}\right.$ aromatic), $2913 \mathrm{~cm}^{-1} \vee(-$ $\mathrm{CH}$ aliphatic), $1615 \mathrm{~cm}^{-1} \vee($ Imine $-\mathrm{N}=\mathrm{CH}-), 1494$, (aromatic $-\mathrm{C}=\mathrm{C}-), 1416(\mathrm{~N}-\mathrm{C}), 1285 \mathrm{~cm}^{-1} \mathrm{v}$ (phenol CO); ${ }^{1} \mathrm{H} \mathrm{NMR}\left(\mathrm{CDCl}_{3}, \mathrm{~d}\right.$, ppm): $7.4(1 \mathrm{H}, \mathrm{N}=\mathrm{C}(\mathrm{H}) ; 6.5-$ $7.11(4 \mathrm{H}, \mathrm{ArH}) ; 3.5\left(4 \mathrm{H},=\mathrm{NCH}_{2} \mathrm{CH}_{2} \mathrm{~N}=\right) .{ }^{13} \mathrm{C} \mathrm{NMR}$ $\left(\mathrm{CDCl}_{3}, \mathrm{~d}^{\top}, \mathrm{ppm}\right): 221.44$ (bonded to phenolic oxygen); 152.65 (aromatic carbons); 48.69 (methylene carbon): GC-MS (m/z): calcd. for $[\mathrm{M}+1]^{+} 268$; found $[\mathrm{M}+1]^{+} 268$.
Method. Solvent extraction method based on batch equilibration was applied in the response methodology approach a Box-Behnken design for the optimization of the reaction conditions according to the matrix as shown in Table 1. Consequently, Co (II) $(100 \mu \mathrm{g})$ was measured each and transferred into a series of $50 \mathrm{~cm}^{3}$ calibrated extraction bottles. $1 \mathrm{~cm}^{3}$ of aqueous $\mathrm{HCl}$ (0.0001-2 $\mathrm{M}$ concentration range) solution was added into the separate bottles, $0.2 \mathrm{~cm}^{3}$ of $0.5 \% \mathrm{H}_{2} \mathrm{BMPDE}$ solution added and $\mathrm{HCl}$ solution added to make up the volume to $5 \mathrm{~cm}^{3}$ with $5 \mathrm{~cm}^{3}$ chloroform added. The phase was treated and the extracted specie determined spectrophotometrically at $465 \mathrm{~nm}$.

The quantity of $\mathrm{Co}$ (II) complexed with $\mathrm{H}_{2} \mathrm{BMPDE}$ $\mathrm{L}(\mu \mathrm{g})$ was thus calculated as shown in equation 1 .

$\mathrm{L}=\frac{\mathrm{V}(\mathrm{Co}-\mathrm{Ce}) / \mathrm{M}}{\mathrm{M}}$

where:

Co is initial $\mathrm{Co}$ (II) concentration, $\mathrm{Ce}$ is the equilibrium $\mathrm{Co}$ (II) concentration, $\mathrm{V}$ is the volume of $\mathrm{Co}$ (II) and $\mathrm{M}$ is the mass of $\mathrm{H}_{2} \mathrm{BMPDE}$. The mechanism of complexation could be represented as in equation 2 where the extraction constant kex and distribution ratio are represented in equation 3 and 4, respectively

$\mathrm{M}^{\mathrm{n}+}+\mathrm{mH}_{3} \mathrm{~B}^{+}+\mathrm{nX}^{-} \stackrel{\mathrm{kex}}{\rightleftharpoons} \mathrm{M}\left(\mathrm{H}_{2} \mathrm{~B}\right){ }_{\mathrm{M}}^{\mathrm{n}+} \mathrm{nX}^{-}+\mathrm{mH}^{+} \ldots 2$

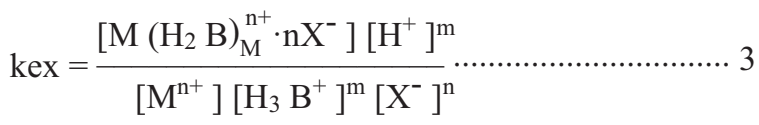

where:

$\mathrm{X}=\mathrm{Cl}^{-}, \mathrm{ClO}_{4}^{-}, \mathrm{NO}_{3}^{-}, \mathrm{OH}^{-}$or $\mathrm{HSO}_{4}^{-}, \mathrm{M}=$ metal cation and $\mathrm{D}$ Distribution ratio

$\log \mathrm{D}=\mathrm{M} \log \left[\mathrm{H}_{2} \mathrm{~B}\right]+\mathrm{n} \log \left[\mathrm{X}^{-}\right]+\mathrm{m} \log \mathrm{K}_{1}+\log \mathrm{kex} \ldots \ldots .4$

Table 1. Variables and experimental design levels for response surface

\begin{tabular}{llll}
\hline \hline Coded values & -1.000 & 0.000 & +1.000 \\
\hline A (Seconds) & 1.00 & 8.00 & 15.00 \\
$\mathrm{~B}(\mathrm{M})$ & 0.50 & 0.25 & 0.0001 \\
$\mathrm{C}\left({ }^{\circ} \mathrm{C}\right)$ & 20.00 & 30.00 & 40.00 \\
$\mathrm{D}(\mu \mathrm{g})$ & 5.00 & 12.50 & 20.00 \\
$\mathrm{E}(\%)$ & 0.05 & 0.525 & 1.00 \\
\hline \hline
\end{tabular}


The process involves ion-association complexes of the type $\left[\mathrm{M}\left(\mathrm{H}_{2} \mathrm{~B}\right] 2 \mathrm{X}^{-}\right.$. In other words, the extraction mechanism of $\mathrm{Co}$ (II)- $\mathrm{H}_{2}$ BMPDE complex formation could be represented as equation 5

$$
\mathrm{Co}^{2+}+\mathrm{H}_{2} \mathrm{BMPDE}+2 \mathrm{OH}^{-} \stackrel{\text { kex }}{\rightleftharpoons} \mathrm{Co}\left(\mathrm{H}_{2} \mathrm{BMPDE}\right)
$$$$
(\mathrm{OH})_{2}
$$

Preparation condition for $\mathrm{Co}(\mathrm{II})-\mathrm{H}_{2} \mathrm{BMPDE}$ complex. $100 \mu \mathrm{g}$ aliquot solution of $\mathrm{Co}$ (II) was added into a $50 \mathrm{~cm}^{3}$ calibrated extraction bottle and 0.0001 $\mathrm{M}$ aqueous $\mathrm{HCl}$ solution was added and then $0.2 \mathrm{~cm}^{3}$ of $\mathrm{H}_{2} \mathrm{BMPDE}$ solution. Volume of the component was made up to $5 \mathrm{~cm}^{3}$ with $\mathrm{HCl}(0.0001 \mathrm{M})$ solution, 10 min for colour development was allowed and $5 \mathrm{~cm}^{3}$ chloroform added. The component was shaken for ten min, allowed to stand, separated and the light brown coloured $\mathrm{Co}$ (II) complex allowed to dry.

Experimental design. In this study, RSM based on Box-Behnken design was used to optimize the reaction conditions for maximum production of the $\mathrm{Co}(\mathrm{II}) \mathrm{bis}\left(2,2^{\prime}-\right.$ methylylidenephenol)diaminoethane complex. The influences of independent variables were used to maximize the quantity of $\mathrm{Co}(\mathrm{II})-\mathrm{H}_{2} \mathrm{BMPDE}$ produced. The range of extraction parameters was effected through experimental design obtained from Box-Behnken central composite(CCD) design. The experiments designed in central composite design (CCD) using Box Behnken approach included 46 experiments of five reaction conditions at three levels $(-1,0,+1)$ with 3 runs at the centre point level. The quadratic model equation which explained the non linear effects of variables on the yield of the complex is given in equation 6 .

$\mathrm{Y}=\mathrm{bo}+\sum_{\mathrm{i}=1}^{\mathrm{k}} \mathrm{bixi}+\sum_{\mathrm{i}=1}^{\mathrm{k}}$ bii Xi $+\sum_{\mathrm{i}=1}^{\mathrm{k}} \sum_{\mathrm{j}}^{\mathrm{k}}=1 \mathrm{bijXiXJ}+\epsilon$ 6

where:

$\mathrm{Y}=$ the quantity of $\mathrm{Co}(\mathrm{II})-\mathrm{H}_{2} \mathrm{BMPDE}$ formed; $\mathrm{bo}=$ the offset term; bi the linear effect; bii = the squared effect and $\mathrm{bij}=$ the interaction effect.

In other words, they represent the regression coefficients of the model obtained by multiple regressions (the linear, quadratic and cross-product effects of the factors on the response, respectively). $\mathrm{Xi}, \mathrm{Xj}=$ the ith extraneous variable and $\Sigma$ the random error. The coefficient of regression $\mathrm{R}^{2}$, the $\mathrm{F}$-test and $\mathrm{P}$-value determines the fitness and significance of the polynomial model.
Average of three replicates data was obtained from the model analysis and responses due to interactions of the extraneous variables were generated.

Regression coefficients, standard errors and significance were obtained from the model with analysis of variance (ANOVA) evaluating the model significance and relationships of the five reaction conditions on the preparation and extraction of $\mathrm{Co}$ (II) metal complex. Consequently, the models were fitted and optimum level of extraneous variables response for maximum extraction and complex formation determined with the probability value of $95 \%$ confidence level for the model terms accepted or rejected (Greferer and Lankmaryr, 2005).

\section{Results and Discussion}

Model fitting and statistical analysis. The experimental values of the yield of the Co(II) bis( $2,2^{\prime}$ - methylylidenephenol) diaminoethane complex at each points based on Box-Behnken experimental design were illustrated in Table 2. The data obtained were used to calculate the coefficients of the quadratic second order polynomial equation (equation 7), used to predict the yield of the complex. The best fitting model was developed through regression analysis using the experimental data. The regression terms determined to be significant were combined into a fitted second order polynomial equation to predict the yield of the complex:

$\mathrm{Y}=2.38+3.22 \mathrm{~A}-2.34 \mathrm{~B}+0.56 \mathrm{C}+3.01 \mathrm{D}+0.22 \mathrm{E}+0.28 \mathrm{AB}$ $+0.80 \mathrm{AC}-2.78 \mathrm{AD}+0.000 \mathrm{AE}+0.28 \mathrm{BC}+2.83 \mathrm{BD}-$ $5.40 \mathrm{~B} \mathrm{E}+0.025 \mathrm{C} \mathrm{D}-5.83 \mathrm{CE}+3.88 \mathrm{DE}+$ $8.84 \mathrm{~A}^{2}+0.92 \mathrm{~B}^{2}+8.66 \mathrm{C}^{2}+6.55 \mathrm{D}^{2}+4.22 \mathrm{E}^{2} \ldots \ldots \ldots \ldots \ldots . .7$

Statistically, the model performance was tested as analysis of variance (ANOVA) and presented in Table 3 . The goodness of fit of the model was checked by coefficient of determination $\left(\mathrm{R}^{2}\right)$. In this analysis, the value of $R^{2}$ is $99.99 \%$ and the value of $\operatorname{Adj}^{2}(99.97 \%)$ is high to show that only $0.001 \%$ of the complexation and extraction was unaccounted for. This entails the fitted second order polynomial model described more than $99.98 \%$ of the process as shown by the significantly high value of Adj $R^{2}(p<0.001)$ of the variations in the experimental data (Shu et al., 2013; Greferer and Lankmaryr, 2005). The F-value of quadratic regression model was 8339.12. The observed lack of fit F-value of 2.43 for the $\mathrm{Co}$ (II) $-\mathrm{H}_{2} \mathrm{BMPDE}$ preparation and extraction shows non significance in relation to the pure 
Table 2. Box-Behnken central composite design and results for RSM

\begin{tabular}{|c|c|c|c|c|c|c|}
\hline $\begin{array}{l}\text { Expt } \\
\text { Run }\end{array}$ & A & B & $\mathrm{C}$ & D & $\mathrm{E}$ & Yield \\
\hline 1 & 1.00 & 0.00 & 30.00 & 12.50 & 0.53 & 11.59 \\
\hline 2 & 15.00 & 0.00 & 30.00 & 12.50 & 0.53 & 17.47 \\
\hline 3 & 1.00 & 0.50 & 30.00 & 12.50 & 0.53 & 6.41 \\
\hline 4 & 15.00 & 0.50 & 30.00 & 12.50 & 0.53 & 13.39 \\
\hline 5 & 8.00 & 0.25 & 20.00 & 5.00 & 0.53 & 14.17 \\
\hline 6 & 8.00 & 0.25 & 40.00 & 5.00 & 0.53 & 15.13 \\
\hline 7 & 8.00 & 0.25 & 20.00 & 20.00 & 0.53 & 20.13 \\
\hline 8 & 8.00 & 0.25 & 40.00 & 20.00 & 0.53 & 21.19 \\
\hline 9 & 8.00 & 0.00 & 30.00 & 12.50 & 0.05 & 4.28 \\
\hline 10 & 8.00 & 0.50 & 30.00 & 12.50 & 0.05 & 10.46 \\
\hline 11 & 8.00 & 0.00 & 30.00 & 12.50 & 1.00 & 15.50 \\
\hline 12 & 8.00 & 0.50 & 30.00 & 12.50 & 1.00 & 0.08 \\
\hline 13 & 1.00 & 0.25 & 20.00 & 12.50 & 0.53 & 17.04 \\
\hline 14 & 15.00 & 0.25 & 20.00 & 12.50 & 0.53 & 21.86 \\
\hline 15 & 1.00 & 0.25 & 40.00 & 12.50 & 0.53 & 16.44 \\
\hline 16 & 15.00 & 0.25 & 40.00 & 12.50 & 0.53 & 24.48 \\
\hline 17 & 8.00 & 0.25 & 30.00 & 5.00 & 0.05 & 13.82 \\
\hline 18 & 8.00 & 0.25 & 30.00 & 20.00 & 0.05 & 12.03 \\
\hline 19 & 8.00 & 0.25 & 30.00 & 5.00 & 1.00 & 6.54 \\
\hline 20 & 8.00 & 0.25 & 30.00 & 20.00 & 1.00 & 20.27 \\
\hline 21 & 8.00 & 0.00 & 20.00 & 12.50 & 0.53 & 13.82 \\
\hline 22 & 8.00 & 0.50 & 20.00 & 12.50 & 0.53 & 8.48 \\
\hline 23 & 8.00 & 0.00 & 40.00 & 12.50 & 0.53 & 14.65 \\
\hline 24 & 8.00 & 0.50 & 40.00 & 12.50 & 0.53 & 10.43 \\
\hline 25 & 1.00 & 0.25 & 30.00 & 5.00 & 0.53 & 8.68 \\
\hline 26 & 15.00 & 0.25 & 30.00 & 5.00 & 0.53 & 20.70 \\
\hline 27 & 1.00 & 0.25 & 30.00 & 20.00 & 0.53 & 20.28 \\
\hline 28 & 15.00 & 0.25 & 30.00 & 20.00 & 0.53 & 21.19 \\
\hline 29 & 8.00 & 0.25 & 20.00 & 12.50 & 0.05 & 8.70 \\
\hline 30 & 8.00 & 0.25 & 40.00 & 12.50 & 0.05 & 21.42 \\
\hline 31 & 8.00 & 0.25 & 20.00 & 12.50 & 1.00 & 20.78 \\
\hline 32 & 8.00 & 0.25 & 40.00 & 12.50 & 1.00 & 10.21 \\
\hline 33 & 1.00 & 0.25 & 30.00 & 12.50 & 0.05 & 11.94 \\
\hline 34 & 15.00 & 0.25 & 30.00 & 12.50 & 0.05 & 18.41 \\
\hline 35 & 1.00 & 0.25 & 30.00 & 12.50 & 1.00 & 12.38 \\
\hline 36 & 15.00 & 0.25 & 30.00 & 12.50 & 1.00 & 18.84 \\
\hline 37 & 8.00 & 0.00 & 30.00 & 5.00 & 0.53 & 12.03 \\
\hline 38 & 8.00 & 0.50 & 30.00 & 5.00 & 0.53 & 1.65 \\
\hline 39 & 8.00 & 0.00 & 30.00 & 20.00 & 0.53 & 12.41 \\
\hline 40 & 8.00 & 0.50 & 30.00 & 20.00 & 0.53 & 13.36 \\
\hline 41 & 8.00 & 0.25 & 30.00 & 12.50 & 0.53 & 2.30 \\
\hline 42 & 8.00 & 0.25 & 30.00 & 12.50 & 0.53 & 2.50 \\
\hline 43 & 8.00 & 0.25 & 30.00 & 12.50 & 0.53 & 2.40 \\
\hline 44 & 8.00 & 0.25 & 30.00 & 12.50 & 0.53 & 2.40 \\
\hline 45 & 8.00 & 0.25 & 30.00 & 12.50 & 0.53 & 2.30 \\
\hline 46 & 8.00 & 0.25 & 30.00 & 12.50 & 0.53 & 2.40 \\
\hline
\end{tabular}

$\mathrm{A}=$ time; $\mathrm{B}=$ acid; $\mathrm{C}=$ temperature; $\mathrm{D}=$ metal conc; $\mathrm{E}=$ ligand conc.

error and as shown $\mathrm{R}^{2}$ value(Greferer and Lankmaryr, 2005). In consideration to this, it could be in inferred that in the predicted model the yield of Co (II) -
$\mathrm{H}_{2}$ BMPDE is accurate as also corroborated by the significant agreement between experimental and predicted values as shown in Fig 1. Table 3 illustrated the $\mathrm{F}$ and $\mathrm{p}$-values a measure of the significance of coefficients. Small $p$ - value and large F-value, shows significant relationship between reaction parameters. The term having $\mathrm{P}>\mathrm{F}$ values less than 0.05 are significant and $\mathrm{P}$ value greater than 0.1 indicates an insignificant model (Shu et al., 2013). Consequently, the reaction parameter with the greatest magnitude on $\mathrm{Co}(\mathrm{II})$ $\mathrm{H}_{2} \mathrm{BMPDE}$ yield was the quadratic term of $\mathrm{A}^{2}$, followed by the quadratic term of $\mathrm{C}^{2}, \mathrm{D}^{2}$ and the linear terms of $\mathrm{A}$, quadratic term of $\mathrm{E}^{2}$ and linear term of $\mathrm{D}(\mathrm{p}<0.001)$. The cross-product $\mathrm{AE}$ and $\mathrm{CD}$ were significant at $1 \%$ level $(\mathrm{p}<0.1)$ while other terms were all significant $(\mathrm{p}$ $>0.001$ ) (Table 3).

Table 3. Analysis of variance (ANOVA) for the fitted quadratic polynomial model and significance test of regression coefficient.

\begin{tabular}{|c|c|c|c|c|c|}
\hline Source & $\begin{array}{l}\text { Sum of } \\
\text { squares }\end{array}$ & df & $\begin{array}{l}\text { Mean } \\
\text { square }\end{array}$ & $\begin{array}{l}\mathrm{F} \\
\text { value }\end{array}$ & $\mathrm{p}$-value \\
\hline Model & 2027.15 & 20 & 101.36 & 8339.12 & $<0.0001$ \\
\hline A & 166.24 & 1 & 166.24 & 13676.92 & $<0.0001$ \\
\hline B & 87.76 & 1 & 87.76 & 7220.74 & $<0.0001$ \\
\hline $\mathrm{C}$ & 5.04 & 1 & 5.04 & 414.31 & $<0.0001$ \\
\hline D & 144.84 & 1 & 144.84 & 11916.59 & $<0.0001$ \\
\hline E & 0.78 & 1 & 0.78 & 64.54 & $<0.0001$ \\
\hline $\mathrm{AB}$ & 0.30 & 1 & 0.30 & 24.89 & $<0.0001$ \\
\hline $\mathrm{AC}$ & 2.57 & 1 & 2.57 & 211.61 & $<0.0001$ \\
\hline $\mathrm{AD}$ & 30.80 & 1 & 30.80 & 2534.26 & $<0.0001$ \\
\hline $\mathrm{AE}$ & 0.000 & 1 & 0.000 & 0.000 & 1.0000 \\
\hline $\mathrm{BC}$ & 0.31 & 1 & 0.31 & 25.90 & $<0.0001$ \\
\hline $\mathrm{BD}$ & 32.09 & 1 & 32.09 & 2640.37 & $<0.0001$ \\
\hline $\mathrm{BE}$ & 116.64 & 1 & 116.64 & 9596.50 & $<0.0001$ \\
\hline $\mathrm{CD}$ & $2.500 \mathrm{E}-003$ & 1 & $2.500 \mathrm{E}-003$ & 0.21 & 0.6541 \\
\hline $\mathrm{CE}$ & 135.72 & 1 & 135.72 & 11166.50 & $<0.0001$ \\
\hline $\mathrm{DE}$ & 60.19 & 1 & 60.19 & 4952.06 & $<0.0001$ \\
\hline$A^{2}$ & 682.77 & 1 & 682.77 & 56174.20 & $<0.0001$ \\
\hline $\mathrm{B}^{2}$ & 7.41 & 1 & 7.41 & 609.39 & $<0.0001$ \\
\hline$C^{2}$ & 654.95 & 1 & 654.95 & 53885.36 & $<0.0001$ \\
\hline $\mathrm{D}^{2}$ & 374.81 & 1 & 374.81 & 30836.92 & $<0.0001$ \\
\hline$E^{2}$ & 155.76 & 1 & 155.76 & 12814.68 & $<0.0001$ \\
\hline Residual & 0.30 & 25 & 0.012 & & \\
\hline \multicolumn{6}{|l|}{ Lack of } \\
\hline Fit & 0.28 & 20 & 0.014 & 2.43 & 0.164 \\
\hline Pure Error & 0.028 & 5 & $5.667 \mathrm{E}-003$ & & \\
\hline Cor Total & 2027.45 & 45 & & & \\
\hline Std. Dev. & 0.11 & & & $\mathrm{R}^{2}$ & 0.9999 \\
\hline Mean & 12.54 & & & Adj $R^{2}$ & 0.9997 \\
\hline C.V.\% & 0.88 & & & Pred $R^{2}$ & 0.9994 \\
\hline
\end{tabular}

$\mathrm{A}=$ time; $\mathrm{B}=$ acid $; \mathrm{C}=$ temperature; $\mathrm{D}$ :metal conc; $\mathrm{E}=$ ligand conc. 


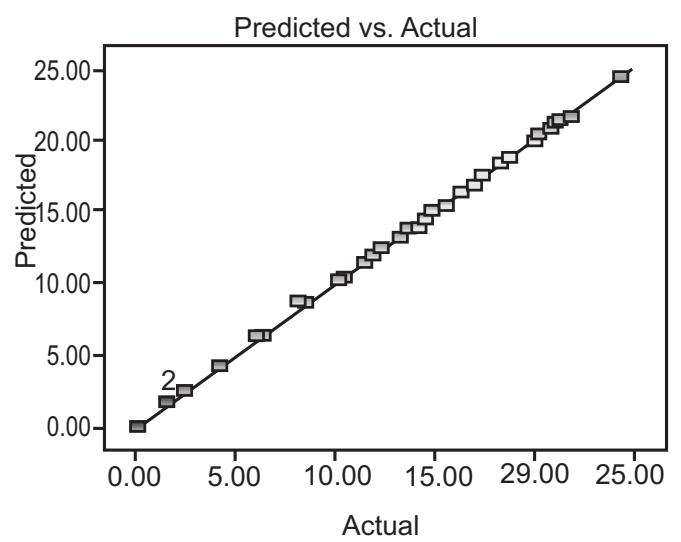

Fig. 1. Comparison between experimental and predicted values for $\mathrm{Co}(\mathrm{II})$ preparation and extraction.

Analysis of response surfaces and contour plots. The interaction of the reaction variables are represented using surface response and contour plots generated by varying two of the reaction variables within the determined range while others are kept at centre point as constant as shown in Fig. 2-9. The response surfaces and contour plots and their shapes provide useful information on the relationship between the reaction parameters and yield of the $\mathrm{Co}$ (II) $-\mathrm{H}_{2} \mathrm{BMPDE}$ complex. Fig. 2 and 8 illustrated the effect of $\mathrm{Co}(\mathrm{II})$ concentration and acid concentration as well as acid concentration and time of extraction. The extraction was executed in the range of 0.1- $0.0001 \mathrm{M}$ acid solution. The extraction was quantitative at $0.001-0.0001 \mathrm{M}$ solution of acid but decreased monotonously at higher acid concentration probably due to degradation of the $\mathrm{H}_{2} \mathrm{BMPDE}$ and of the complex as it is formed. This is further buttressed in Fig. 3 and 6 as complexation could be hindered in high acid media and high temperature can degrade the $\mathrm{H}_{2} \mathrm{BMPDE}$ hindering complexation.

Figures 4-9 illustrated the relationship between several reaction variables such as time, amount of $\mathrm{H}_{2} \mathrm{BMPDE}$ and temperature in the preparation and extraction of $\mathrm{Co}$ (II) $\mathrm{H}_{2} \mathrm{BMPDE}$. When $\mathrm{Co}$ (II) concentration increased from $5 \mu \mathrm{g}$ to $15 \mu \mathrm{g}$, $\mathrm{Co}$ (II) $\mathrm{H}_{2} \mathrm{BMPDE}$ extracted increased. Above $15 \mu \mathrm{g}$ of the $\mathrm{Co}(\mathrm{II})$, there was no observed increase in $\mathrm{Co}(\mathrm{II})-\mathrm{H}_{2} \mathrm{BMPDE}$ extracted. Unavailability of $\mathrm{H}_{2} \mathrm{BMPDE}$ could be a reason behind this observation. Varying temperature from $20-30{ }^{\circ} \mathrm{C}$ increased the quantity of $\mathrm{Co}$ (II)- $\mathrm{H}_{2} \mathrm{BMPDE}$ produced but above $39^{\circ} \mathrm{C}$, degradation and or demetallation of
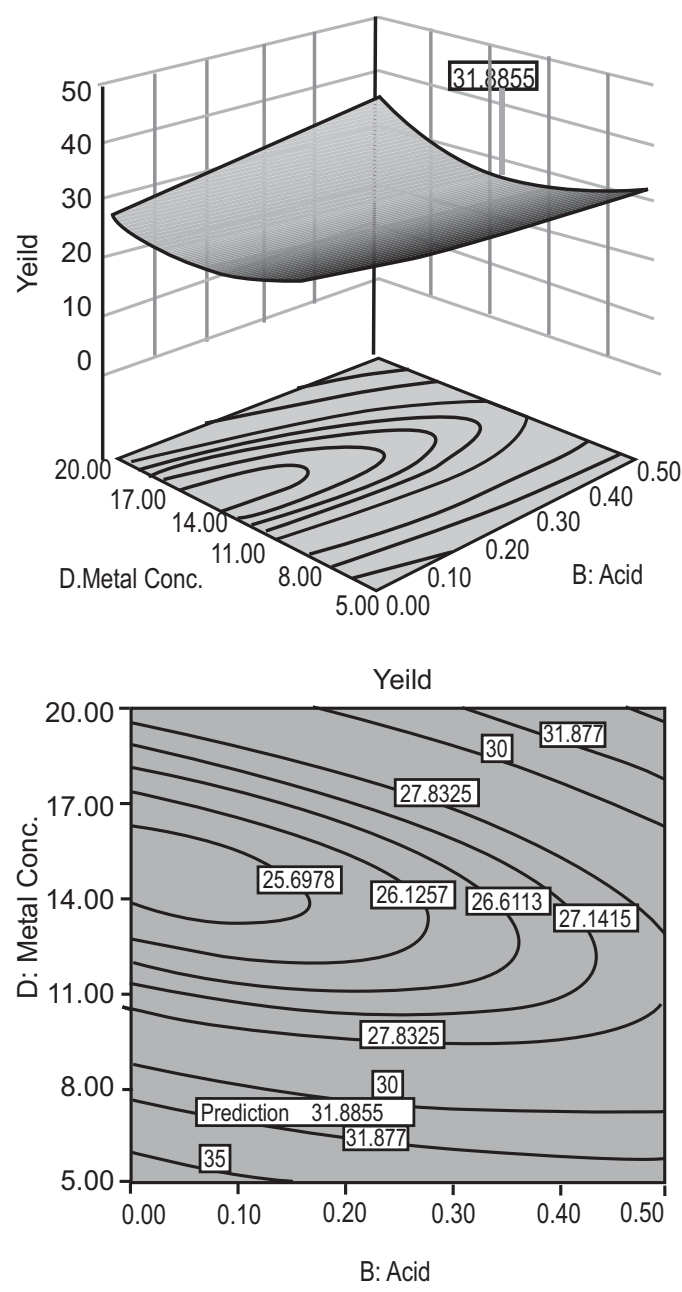

Fig. 2. Surface plot and contour plot of the combined effects of metal and acid concentration.

$\mathrm{H}_{2}$ BMPDE sets in leading to decreased yield (Baleizao and Garcia, 2006).

Synthesis and characterization of the ligand. The synthetic route for the ligand is illustrated in Fig. 1 by the condensation of ethylenediamine and salicylaldehyde in the ratio of 1:2. Recrystallization of the crude product gave $64.45 \%$ yield for which GC-MS spectral data $\left([\mathrm{M}+1]^{+} 268\right.$ with fragments peaks at 206, 176, 172, 155 and 127) and elemental analyses gave satisfactory result. The UV- vis spectrum of $\mathrm{H}_{2} \mathrm{BMPDE}$ shows three absorptions at 260, 285 and $335 \mathrm{~nm}$ indicating $\pi$ $-\pi^{*}, \mathrm{n}-\pi^{*}$ and charge transfer transitions of the phenyl or imine ring, non-bonding electrons in the nitrogen and intraligand charge transfer transitions, respectively (Yang et al., 2010). The ligand FT-IR, 

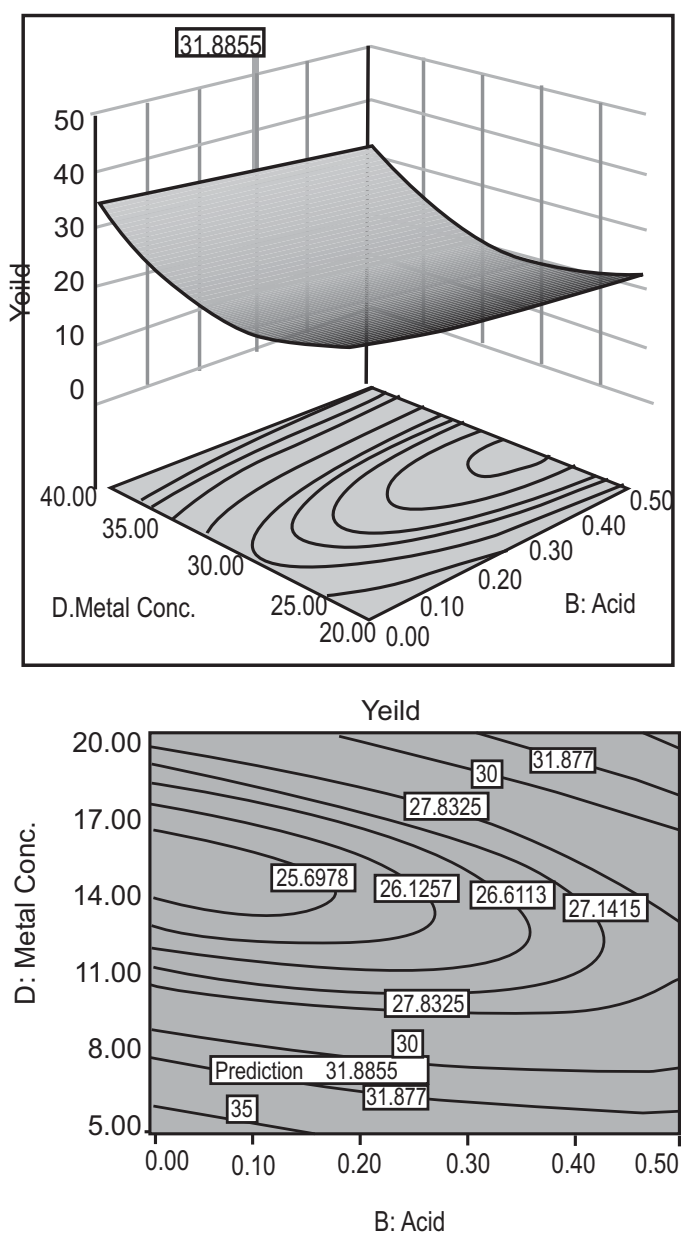

Fig. 3. Surface plot and contour plot of the combined effects of temperature and acid concentration.

showed broad peak of phenolic hydroxyl group at $3401 \mathrm{~cm}^{-1}$ and $\mathrm{C}=\mathrm{N}$ stretching frequency at $1615 \mathrm{~cm}^{-1}$ establishing that the Schiff base was actually synthesized (Yang et al., 2010). Similarly, characteristic absorption assignable to $\mathrm{C}=\mathrm{O}$ and $\mathrm{NH}_{2}$ present in the precursor compounds disappeared in the spectra of the ligand establishing further the synthesis of the ligand. Strong band at $1285 \mathrm{~cm}^{-1}$ was assigned to phenol $\mathrm{C}-\mathrm{O}$ group (Yang et al., 2010)

The absence of amine proton signals in the spectra of the ligand is a confirmation of the condensation of the precursor compounds, ethylenediamine and salicylaldehyde (Yang et al., 2010). $\mathrm{H}_{2}$ EBNMD is a symmetrical molecule with the methyne proton observed as doublet at $3.5 \mathrm{ppm}(4 \mathrm{H})$ and azomethine proton shown as quartet $(1 \mathrm{H})$ at $7.4 \mathrm{ppm}$ (Yang et al., 2010; Ansari et
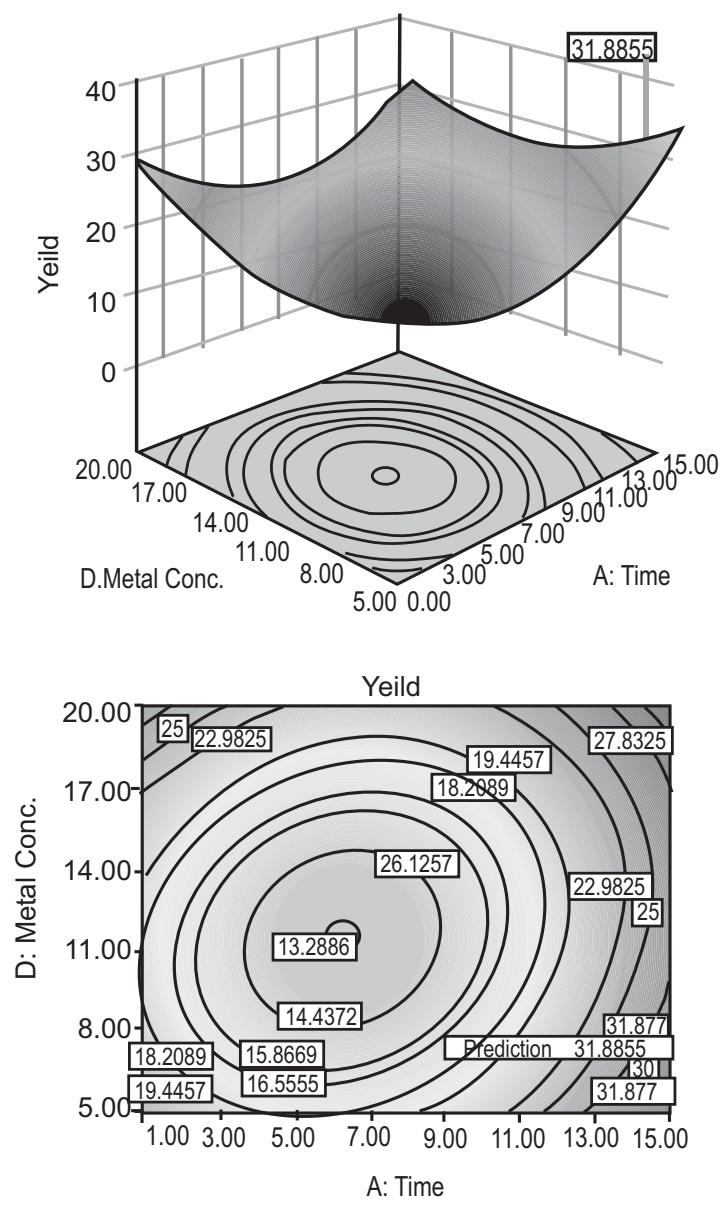

Fig. 4. Surface plot and contour plot of the combined effects of metal concentration and time.

al., 2009) whereas hydrogen of aromatics ring was displayed at $7.11 \mathrm{ppm}(3 \mathrm{H})$ due to coupling of 4 hydrogen atoms in the ring. ${ }^{13} \mathrm{C}$ NMR spectrum of $\mathrm{H}_{2} \mathrm{BMPDE}$ displayed carbon atom bonded to phenolic oxygen at $221.44 \mathrm{ppm}$, aromatic carbons at 152.65 ppm and methylene carbon at $48.69 \mathrm{ppm}$.

Kinetics of complexation. Kinetics experiment for the complexation of cobalt(II) to the $\mathrm{H}_{2} \mathrm{MPDE}$ was effected at different contact times of 1,3,5,10 and 15 min with constant $\mathrm{H}_{2} \mathrm{BMPDE}(0.5 \%)$ and aqueous $\mathrm{HCl} 10^{-4} \mathrm{M}$

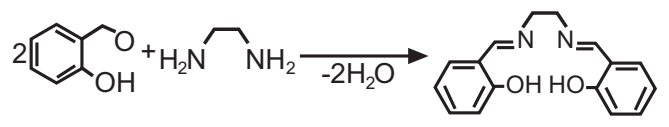

Scheme 1. Synthetic route for bis (2,2'-methylylidene-phenol) diaminoethane. 

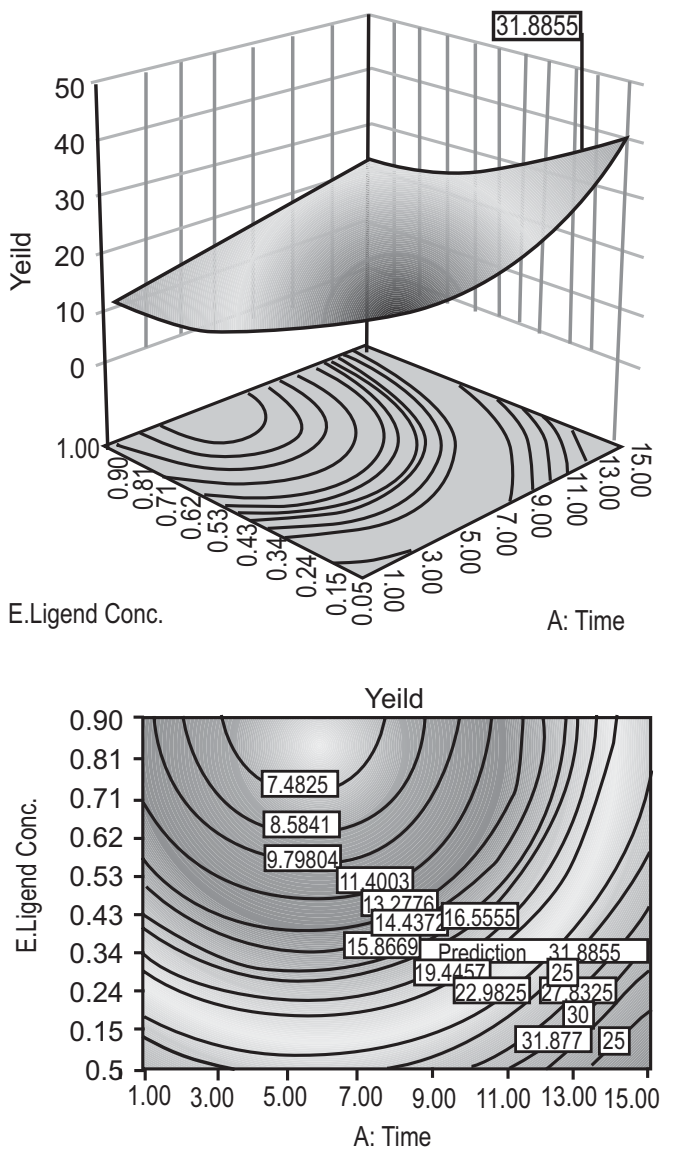

Fig. 5. Surface plot and contour plot of the combined effects of ligand concentration and time.

concentrations to determine the equilibrium time and to model the process. Two commonly used kinetic models i.e., Lagergren Pseudo-first order and Pseudosecond order model shown in equations 8 and 9, respectively were applied on the complexation data.

$\operatorname{In}(q e-q t)=I n q e-k_{1} t$

$\mathrm{t} / \mathrm{qt}=1 / \mathrm{K}_{2} \mathrm{qe}^{2}+\mathrm{t} / \mathrm{qe}$ 9

where:

the quantity of $\mathrm{Co}$ (II) complexed with $\mathrm{H}_{2} \mathrm{BMPDE}$ at equilibrium $(\mu \mathrm{g})$ is qe, qt $(\mu \mathrm{g})$ the quantity of $\mathrm{Co}(\mathrm{II})$ complexed and $\mathrm{K}_{1}$ and $\mathrm{K}_{2}$ the rate constants of pseudofirst order and second order kinetic models, respectively. When $\operatorname{In}(q e-q t)$ is plotted against $t$ for pseudo-first order model and $t / q t$ plotted against $t$ for second order model the observed slopes are $K_{1}$ and $K_{2}$, respectively
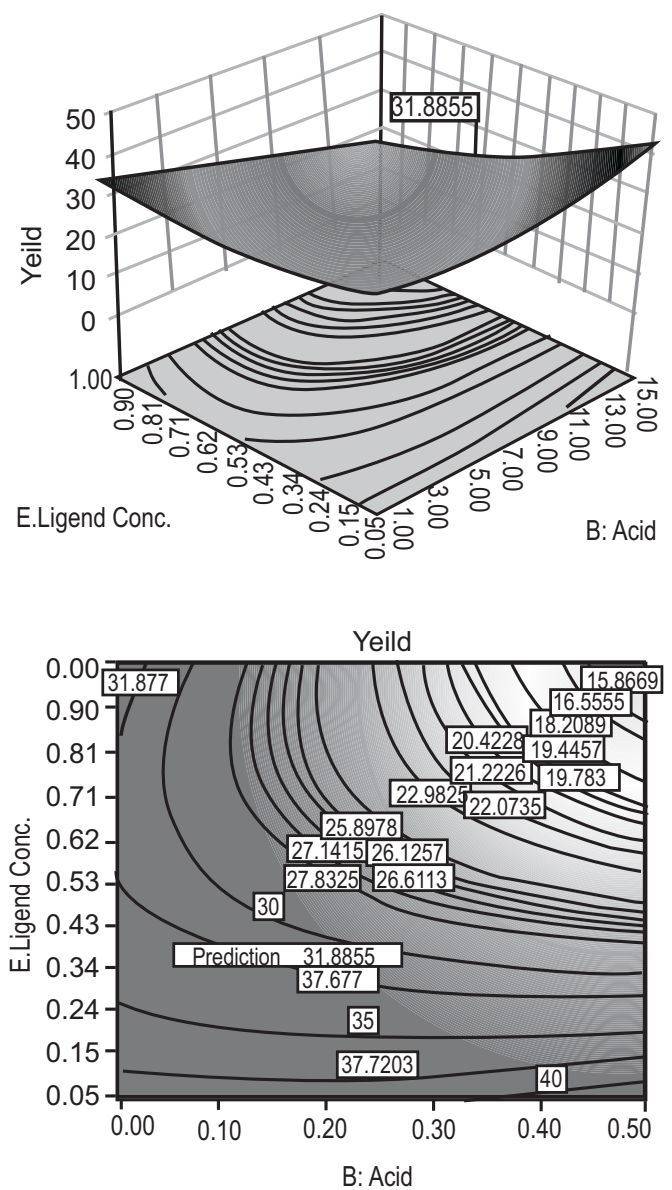

Fig. 6. Surface plot and contour plot of the combined effects of ligand and acid concentration.

(Fig. 10 and 11). The high regression coefficient of pseudo-second order kinetic model $\left(\mathrm{R}^{2}=0.9948\right)$ and low regression coefficient of pseudo-first order kinetic model $\left(\mathrm{R}^{2}=0.3382\right)$ indicated that complexation process is best described by pseudo -second order kinetic model.

Temperature effect. The temperature effect on the complexation process of cobalt (II) ions on $\mathrm{H}_{2} \mathrm{BMPDE}$ showed that the reaction increased with rise in room temperature. This was done by performing the extraction at different temperatures of 288, 293, 298 and $303 \mathrm{~K}$ as shown in Table 4. Figure 12 illustrated the effect of temperature on the complexation of cobalt (II) ions on $\mathrm{H}_{2} \mathrm{BMPDE}$ (Vant Hoff plot) represented as plot of Inko against $1 / T$. The increased complexation of the cobalt(II) ion onto the $\mathrm{H}_{2} \mathrm{BMPDE}$ with rise in temperature illustrated that the complexation process could be endothermic (El-Bindary et al., 2013). The complexation 

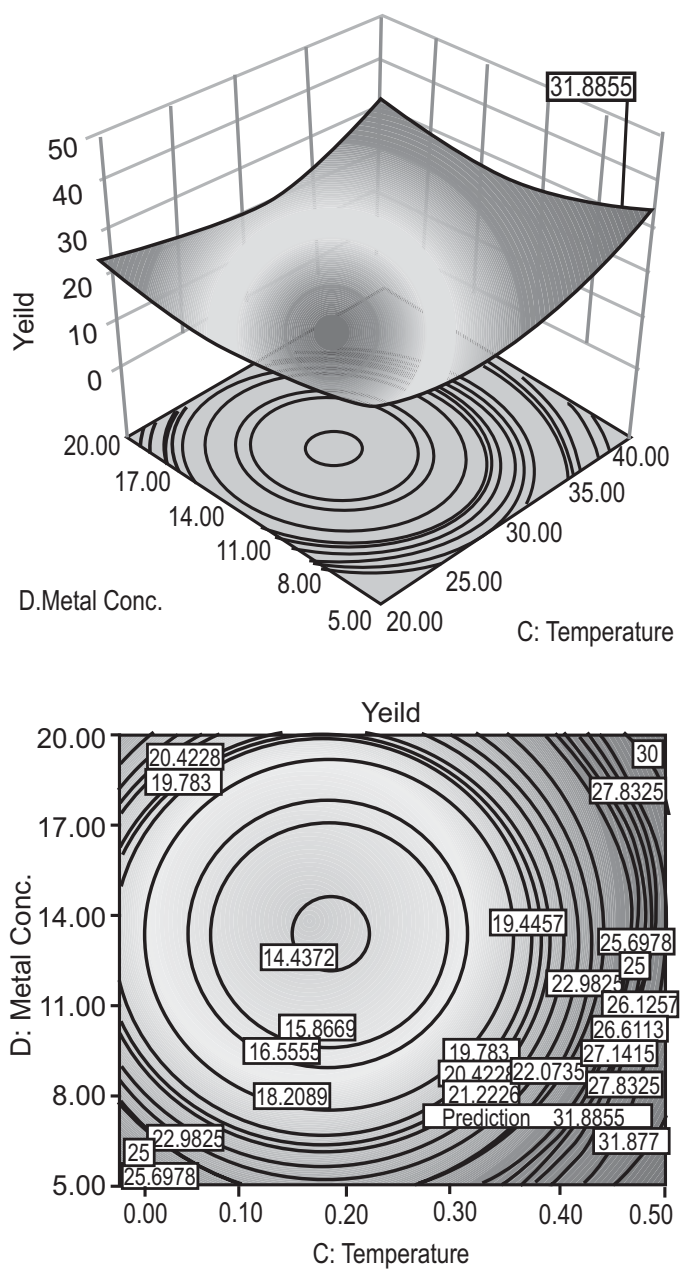

Fig. 7. Surface plot and contour plot of the combined effects of metal concentration and temperature.

thermodynamic parameters were calculated from the variation of the thermodynamic equilibrium constant, $\mathrm{K}_{0}$ (equation 10) at varied temperatures. Thus,

$\mathrm{K}_{\mathrm{o}}={ }^{\mathrm{C}_{\mathrm{I}}} \mathrm{C}_{2}$

where:

$\mathrm{C}_{1}=$ the quantity of cobalt(II) complexed per unit mass of $\mathrm{H}_{2} \mathrm{BMPDE}$ and $\mathrm{C}_{2}=$ the concentration of cobalt(II) in the aqueous phase (Juan et al., 2003).

The standard entropy change of complexation $\left(\Delta S^{0}\right)$, standard enthalpy change of complexation $\left(\Delta \mathrm{H}^{\mathrm{o}}\right)$, the standard free energy change (Gibb's free energy) $\left(\Delta G^{0}\right)$ and stability constant for complex formation $(\beta n)$ of
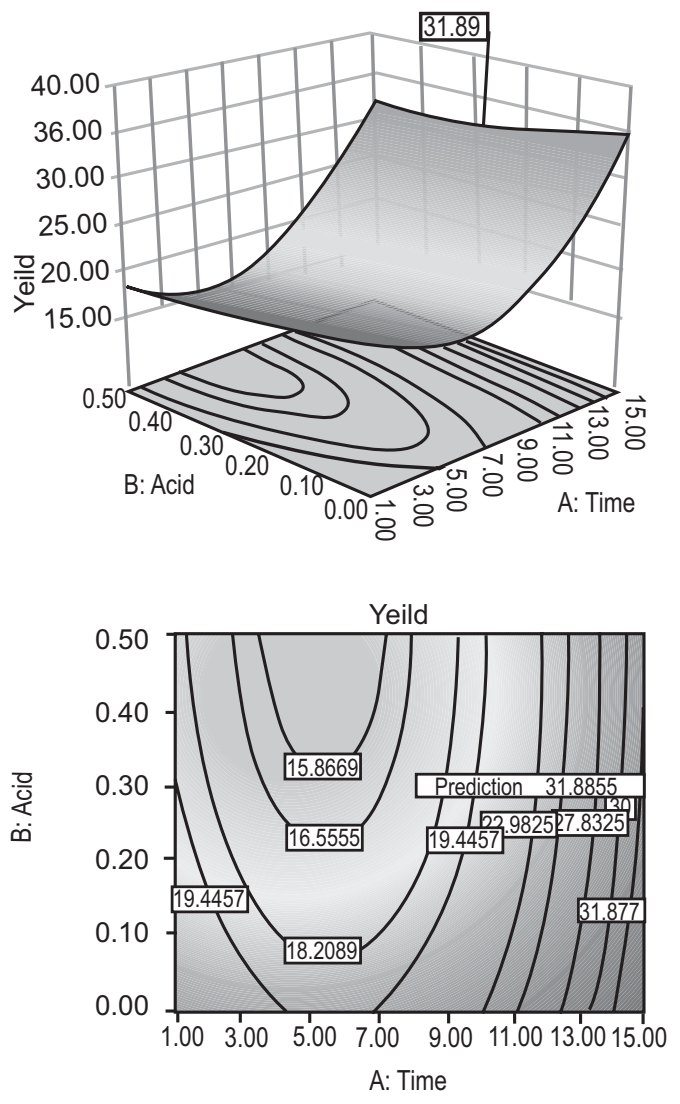

Fig. 8. Surface plot and contour plot of the combined effects of acid concentration and time.

the cobalt(II) ion and $\mathrm{H}_{2} \mathrm{BMPDE}$ were calculated as illustrated in equations 11,12 and 13.

$\mathrm{InK}_{\mathrm{o}}=\frac{\left(\Delta \mathrm{S}^{\mathrm{o}}\right)}{\mathrm{R}}-\frac{\left(\Delta \mathrm{H}^{\mathrm{o}}\right)}{\mathrm{RT}}($ Vant Hoff plot $)$

$\Delta \mathrm{G}^{\mathrm{o}}=-\mathrm{RTInK}_{\mathrm{o}}$

$\Delta \mathrm{G}^{\mathrm{o}}=-2.303 \mathrm{RT} \beta \mathrm{n}$

Temperature is $\mathrm{T}$ in $\mathrm{K}$ and universal gas constant $\mathrm{R}$ in $\mathrm{KJ} / \mathrm{Mol} / \mathrm{k}$. Gibb's free energy change values are negative illustrating the complex formation to be feasible and spontaneous. The positive sign of enthalpy change, the negative value of entropy change and the values of stability constant confirmed the fact that the complexation process was endothermic, involved solvation process with decreased randomness after extraction of $\mathrm{Co}^{2+}$ ion and the complex formed stable 

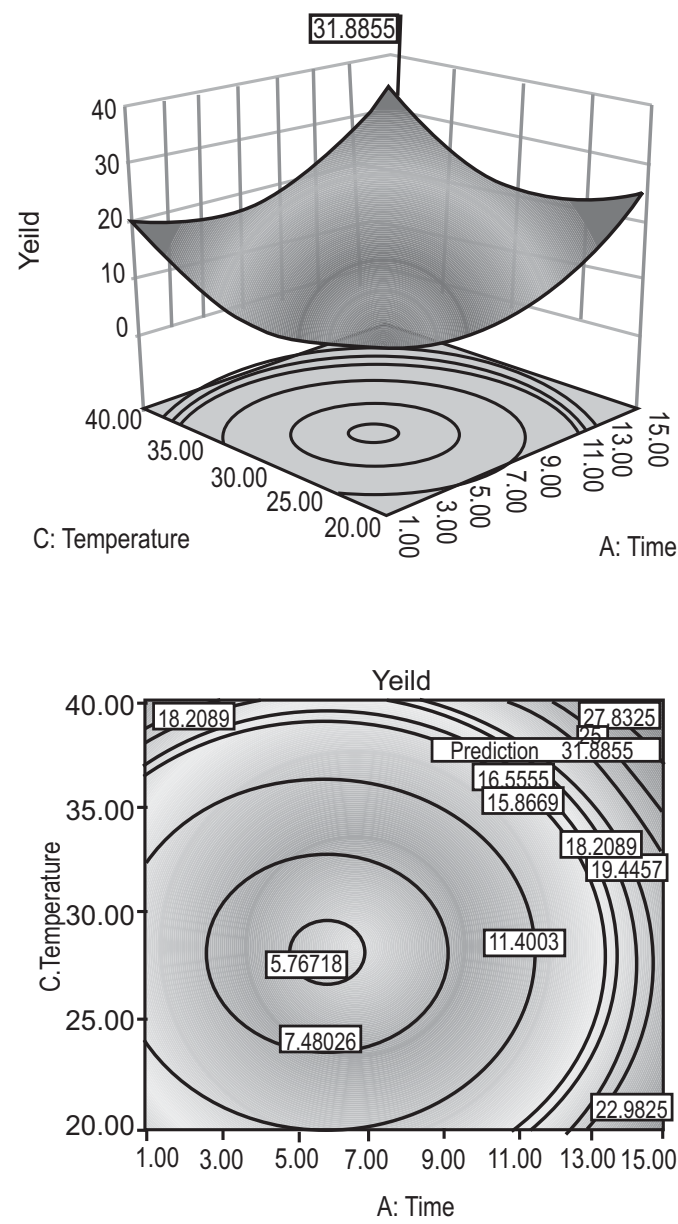

Fig. 9. Surface plot and contour plot of the combined effects of temperature and time.

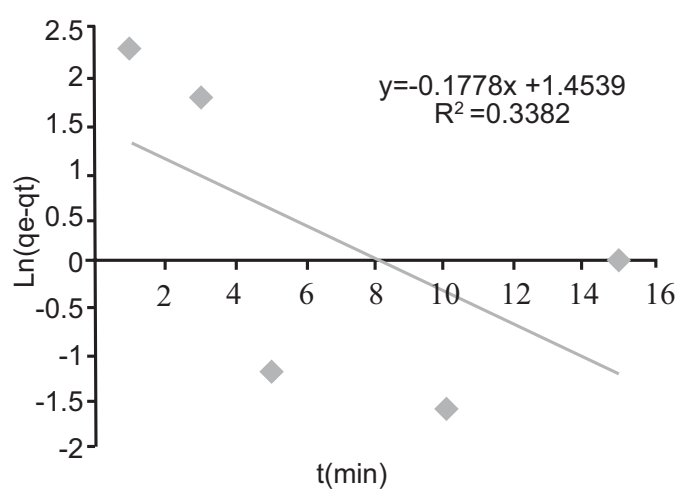

Fig. 10. Lagergran pseudo-first order kinetic model plot for $\mathrm{Co}(\mathrm{II})-\mathrm{H}_{2} \mathrm{BMPDE}$

respectively (El-Bindary et al., 2013; Eun-Jook et al., 2008; Laura et al., 1991; Lloret et al., 1991). The observed process could be attributed to a replacement

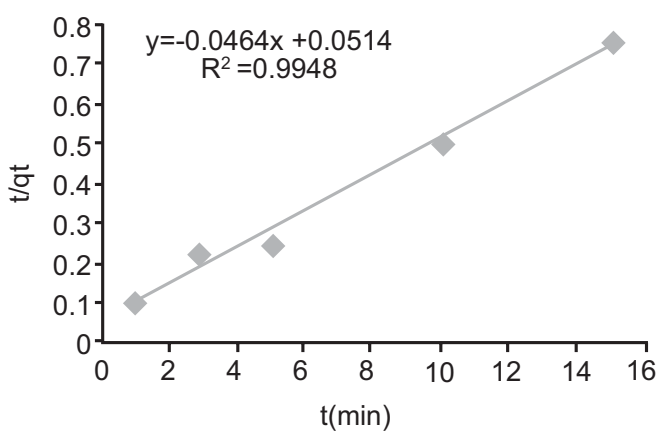

Fig. 11. Lagergran pseudo-second order kinetic model plot for $\mathrm{Co}$ (II)- $\mathrm{H}_{2} \mathrm{BMPDE}$

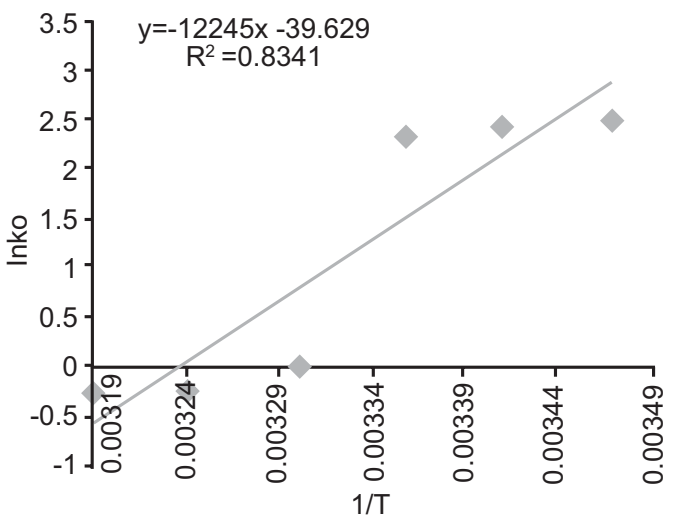

Fig. 12. Vant Hoff plot of InKo against $1 / \mathrm{T}$ for $\mathrm{Co}(\mathrm{II})-\mathrm{H}_{2} \mathrm{BMPDE}$

of some water molecules from the coordination sphere with a positively charged species. Values of thermodynamic parameters been negative indicate more ordered state of complexation (El-Bindary et al., 2013) and thus the ligand demonstrated the potential as a metal ion chelator.

Complexation isotherms. Langmuir and Freundlich isotherms were used to study the non linear relationship between the $\mathrm{Co}$ (II) complexed on the $\mathrm{H}_{2} \mathrm{BMPDE}$ and the $\mathrm{Co}$ (II) ion uncomplexed (Mourabet et al., 2015; Samir et al., 2010; Hall et al., 1966). Langmuir model is expressed by equation 14

$\mathrm{qe}=\mathrm{Q}_{\mathrm{m}} \frac{\mathrm{bCe}}{1}+\mathrm{bCe}$

$\mathrm{Ce}(\mu \mathrm{g})=$ the equilibrium concentration $\mathrm{Co}(\mathrm{II})$ ion, qe $(\mu \mathrm{g})=$ the quantity of $\mathrm{Co}(\mathrm{II})$ ion per unit mass of $\mathrm{H}_{2} \mathrm{BMPDE}, \mathrm{Qm}$ and $\mathrm{b}=$ complexation capacity and 
Table 4. Vant Hoff thermodynamic parameters of $\mathrm{Co}(\mathrm{II})-\mathrm{H}_{2} \mathrm{BMPDE}$ complex.

\begin{tabular}{lllllll}
\hline \hline Metal & $\mathrm{T}(\mathrm{K})$ & $\mathrm{InK}_{0}$ & $\mathrm{Bn}$ & $\Delta \mathrm{G}^{0}(\mathrm{KJ} / \mathrm{Mol})$ & $\Delta \mathrm{H} 0(\mathrm{KJ} / \mathrm{Mol})$ & $\Delta \mathrm{S}(\mathrm{KJ} / \mathrm{MolK})$ \\
\hline Co(II) & 288 & 2.495 & 1.08 & -5.97 & 14680.49 & -47.51 \\
& 293 & 2.429 & 1.05 & -5.97 & & \\
& 298 & 2.31 & 0.985 & -5.62 & & \\
& 303 & 0 & -0 & 0 & & \\
\hline \hline
\end{tabular}

Legend: $\mathrm{T}=$ temperature, $\Delta \mathrm{S}=$ entropy change, $\Delta \mathrm{H}=$ enthapy change, $\beta \mathrm{n}=$ stability constant, $\Delta \mathrm{G}^{0}=\mathrm{Gibb}$ ` free energy.

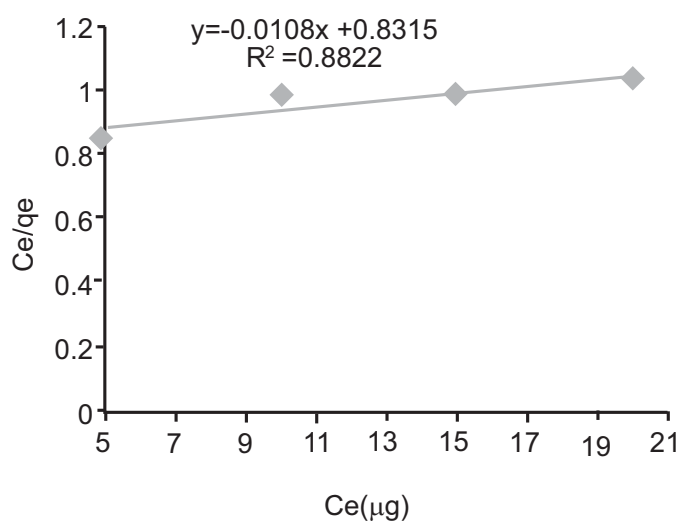

Fig. 13. Freundlich isotherm model plot for $\mathrm{Co}(\mathrm{II})$ $\mathrm{H}_{2} \mathrm{BMPDE}$

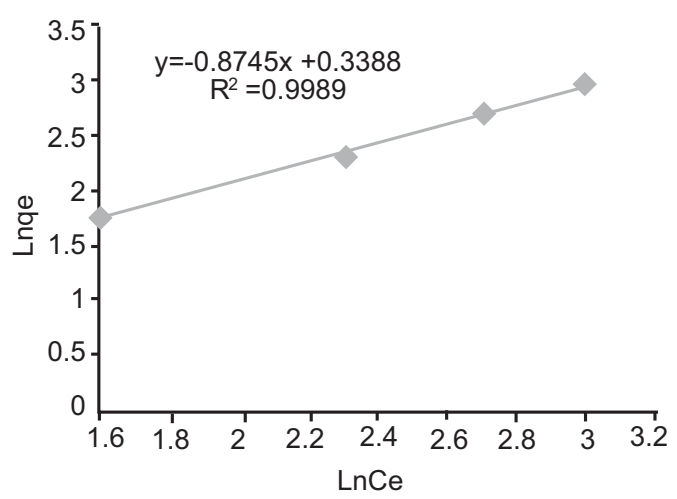

Fig. 14. Freundlich isotherm model plot for $\mathrm{Co}(\mathrm{II})$ $\mathrm{H}_{2} \mathrm{BMPDE}$

complexation rate, respectively with values determined graphically from equation 15 and shown in Fig. 13, The affinity of $\mathrm{Co}$ (II) ions to $\mathrm{H}_{2} \mathrm{BMPDE}$ derived from Langmuir parameter $\mathrm{b}$ was employed in getting the dimensionless separation factor RL expressed in equation 16. Co is the original $\mathrm{Co}$ (II) ion concentration and $\mathrm{b}$ the Langmuir isotherm model constant. The RL values for the $\mathrm{Co}$ (II) ion complexation on $\mathrm{H}_{2} \mathrm{BMPDE}$ is between 0 and $\mathrm{I}$ and shows that the complexation process is favourable (Mourabet et al., 2015; Samir et al., 2010). The Freundlich model is shown in equation 17 with $\mathrm{n}$ as complexation intensity, $\mathrm{K}_{\mathrm{F}}$ complexation capacity obtained as constants representing intercept and slope of the linear plot of In qe against In Ce (Fig. 14). The model constants as calculated with the coefficient of determination for Langmuir $\left(\mathrm{R}^{2}=0.8822\right)$ and Freundlich $\left(\mathrm{R}^{2}=0.9979\right)$ illustrates strong correlation.

$\frac{\mathrm{Ce}}{\mathrm{qe}}=\frac{\mathrm{Ce}}{\mathrm{Qm}}+\frac{1}{\mathrm{bQm}}$

$\mathrm{RL}=\frac{1}{1}+\mathrm{bCo}$ 16

$\mathrm{qe}=\mathrm{K}_{\mathrm{F}} \mathrm{Ce}^{1 / \mathrm{n}}$ 17

Inqe $=\operatorname{InK} f+\frac{1}{1} \operatorname{InCe}$

\section{Conclusion}

The synthesis of Co(II) bis (2,2'-methylylidenephenol) diaminoethane has been described for industrial scale production. The process has also been shown to be efficient, easy and effective. The optimal conditions for the preparation and extraction of $\mathrm{Co}(\mathrm{II})$ bis $\left(2,2^{\prime}-\right.$ methylylidenephenol)diaminoethane was $0.30 \%$ $\mathrm{H}_{2}$ BMPDE, $6.22 \mu \mathrm{g}$ metal ion concentration, a temperature of $39.27^{\circ} \mathrm{C}$, extraction time of $14.19 \mathrm{~min}$, acid concentration of $10^{-4} \mathrm{M}$ and one cycle extraction. Under these optimized conditions, the predicted yield was $31.89 \mu \mathrm{g}$ which was in close agreement with the experimental value and suggests that the model was satisfactory and accurate. Thermodynamic studies indicated that the complexation is feasible, spontaneous, and endothermic and solvation process involved. The high regression coefficient observed from the pseudosecond order kinetic model $\left(\mathrm{R}^{2}=0.9948\right)$ as against pseudo-first order kinetic model $\left(\mathrm{R}^{2}=0.3382\right)$ indicated that pseudo -second order kinetic model best described 
the complexation process. The complexation of cobalt(II) ions on the $\mathrm{H}_{2} \mathrm{BMPDE}$ correlated well with both Langmuir $\left(\mathrm{R}^{2}=0.8822\right)$ and Freundlich $\left(\mathrm{R}^{2}=0.9979\right)$ isotherms. Thus, the process developed has been shown to be stable, cheap, environmentally friendly, and less laborious and can be applied in the industrial synthesis of the compound.

\section{Acknowledgement}

The authors are grateful to Ebonyi State University, Abakaliki TETFund Seed Grant (Ref No: EBSU/ TETFund /IBR/2015/10) for financial assistance.

Conflict of Interest. The authors declare no conflict of interest

\section{References}

Ansari, K. L., Grant, J .D., Woldemarian, G. A., Kasiri, S., Mandal, S.S.2009 .Iron(III)salen complexes with less DNA cleavage activity exhibit more efficient apoptosis in $\mathrm{MCF}_{7}$ cells. Organic Biomolecular Chemistry, 7: 926-932.

Bae, H.J., Hwang, K.Y., Lee, M.H., Do, Y.2011. Salenaluminium complexes as host materials for red phosphorescent organic light emitting diodes. Bulletin Korean Chemical Society, 32: 3290-3294.

Baleizao, C., Garcia, H. 2006. Chiral salen complexes: An overview to recoverable and reusable homogeneous and heterogeneous catalysts. Chemistry Review, 106: 3987-4043.

Cozzi, P.G.2004. Metal -salen Schiff base complexes in catalysis. Practical aspects. Chemical Society Review, 33: 410-421

Dardfarnia, S., Haji Shabani, A.M., Kazemi, E., Khormizi, S.A.H., Tammadon, F. 2015. Synthesis of nanopore size $\mathrm{Ag}(\mathrm{I})$-imprinted polymer for the extraction and preconcentration of silver ions followed by its determination with atomic absorption spectrometry and spectrophotometry using localized surface plasmon resonance peak of silver nanoparticles. Journal of Brazilian Chemical Society, 26: 1180-1190.

Doctrow, S.R., Huffman, K., Marcus, C.B., Tocco, G., Malfroy, E., Adinolfi,.CA., Kruk, H., Baker, K., Lazarowych, N., Mascarenhas, J., Malfroy, B. 2002. Salen manganese complexes as catalytic scavengers of hydrogen peroxide and cytoprotective agents: structure- activity relationship studies. Journal of Medicinal Chemistry, 45: 45-49.
El- Bindary, A- A., El- Sonbati, A.Z., Diab, M.A., AbdEl Kader, M.K. 2013. Potentiometric and thermodynamic studies of some schiff base derivative of 4- aminoantipyriane and their metal complexes. Journal of Chemistry, 1155: 682186 http: // dt. doi org / 10.1155/2013/602186

Eun-Jook, K., Young Sang, K., Young-Moon, S. 2008. Studies on solvent extraction using salphen for separative determination of trace $\mathrm{Fe}$ (II) and $\mathrm{Fe}$ (III) in natural water samples. Bulletin of Korean Chemical Society, 29: 99-102.

Gfrerer, M., Lankmaryr, E.2005. Screening, optimization and validation of microwave assisted extraction for the determination of persistent organo-chlorine pesticides. Analytica Chimica Acta, 533: 203-211.

Hall, K. L., Eagletow, L. C., Acrivos, A., Vermeulen, T.1966.Pore and solid kinetics in fixed-bed adsorption under constant pattern conditions. Industrial Engineering Chemistry Fundamental, 5: 212-223.

Ishikawa, Y., Eguchi, H. 2013. Metal Salen Complex Derivative and Process for Production Thereof. US Patent No. 1002939399A1, $1^{\text {st } J u l y, ~} 2013$.

Jiao, H., Peng, W. Z., Xu, C.2013. Extraction performance of bisphenol $\mathrm{A}$ from aqueous solutions by emulsion liquid membrane using response surface methodology. Desalination, 313: 36-43.

Juan, M.B., Eva, A., Ana, M. G., Luis, C.2003. Data analysis in the determination of stoichiometries and Stability constants of complexes. Analytical Science, 19: 1431- 1439.

Laura, C., Mauro, I., Piero, L., Lucio, S. 1991. Spectrophotometric study of the equilibria between Ni(II) Schiff base complexes and alkaline -earth or nickel(II) cations in acetonitrile solution. Journal of Inorganic Chemistry, 38: 5519-5525.

LLoret, F., Miguel, M., Juan, F., Miguel, J., Isabel, C.W.1991. Solution chemistry of $\mathrm{N}, \mathrm{N}^{\prime}$-ethylenebis (salicylideneimine) and its Copper(II), Nickel(II) and Iron(III) Complexes. Inorganic Chimica Acta, 189: 195-206.

Mourabet, M., EL Rhilassi, A., Boujaady, H., BennaniZiatni, M., EL Hamri, R., Taitai, A. 2015. Removal of fluoride from aqueous solution by adsorption on hydroxyapatite using response surface methodology. Journal of Saudi Chemical Society, 19: 603-615.

Peiris, M. C.R., Udugala- Ganehenege, M.Y. 2015. Electrocatalytic activity of bis (salicylidene) ethylenediamino) $\mathrm{Ni}$ (II) complex for $\mathrm{CO}_{2}$ 
reduction. International Journal of Environmental Science and Development, 7: 91-94.

Sakineh, M., Razieh, Y. 2013. Synthesis and antioxidant activities of [5-fluoro N, N ${ }^{\mathrm{I}}$-bis (salicylidene) ehtylenediamine] and [3,5-fluoro $\mathrm{N}, \mathrm{N}^{\mathrm{I}}$-bis (salicylidene) ethylenediamine] Manganese(III) complexes. Iran Journal of Chemistry and Chemical Engineering, 32: 67-75.

Samir, A.A., Saber, E. M., Abdulrahman, A.F. 2010. Potentiometric, spectrophotometric, conductimetric and thermodynamic studies on some transition metal complexes derived from 3-methyl-1-phenyland 1,3,- diphenyl- 4-arylazo- 5- pyrazolones. Nature and Science, 2: 793- 803.

Shu, G., Dai, C., Chen, H., Wang, X.2013. Application of Box-Behnken design in optimization crude polysaccharides from fruits of Tribulus terristris L. Journal of Chemistry and Pharmaceutical Research, 5: 342-350.

Starkie, C. 2015. 12 $2^{\text {th }}$ Green houseGas Control Technologies Conference, Advances in carbon capture and storage research. Johnson Matthey
Technology Review, 59: 182-187.

Wang, X .B., Chi, Y. 2012. Preparation of microwave phosphorylated soy protein isolates through a Box - Behnken model optimization. Journal of Food, 10: 210-215.

Woldemarian, G. A., Mandal, S.S. 2008. Iron(III) salen damages DNA and induces apoptosis in human cell via mitochondrial pathway. Journal of Inorganic Biochemistry, 102: 740-747.

Yang, S., Kon, H., Wang, H., Chang, K., Wang, J. 2010. Efficient electrolyte of N, NI-bis (salicylidene) ethylenediamine zinc(II) iodide in dye-sensistized solar cells. New Journal of Chemistry, 34: 313-317.

Yuan, R., Chau, Y., Lin, D., Li, D., Yu, R.1993. Schiff base complexes of Cobalt(II) as neutral carrier for highly selective iodide electrodes. Analytical Chemistry, 65: 2572-2575.

Zhang, Y.Y., Liu, J.H. 2011. Optimization of process conditions for preparing an iron-polysaccharide complex by rēsponse surface methodology. Chemical and Biochemical Engineering Quarterly, 25: $75-81$ 